\title{
Rock deformation studies in the Mineral Mountains and Sevier Desert of west-central Utah: Implications for upper crustal low-angle normal faulting
}

\author{
Mark H. Anders* \\ Nicholas Christie-Blick \\ Stewart Wills \\ Department of Earth and Environmental Sciences and Lamont-Doherty Earth Observatory, Columbia University, Palisades, \\ New York 10964-8000, USA \\ Scot W. Krueger ${ }^{\dagger}$ \\ ARCO Exploration and Production Technology, 2300 West Plano Parkway, Plano, Texas 75075, USA
}

\section{ABSTRACT}

The Cave Canyon detachment, a low-angle normal fault that crops out in the Mineral Mountains, west-central Utah, has been interpreted as a hanging-wall splay of a much larger structure (the Sevier Desert detachment) that was influential in development of the idea that low-angle normal faults play a role in crustal extension. The Cave Canyon detachment provides expectations for the deformational features that might be expected along the hypothesized Sevier Desert detachment, which is not exposed in outcrop and is inferred to exist primarily on the basis of seismic reflection data.

The footwall of the Cave Canyon detachment is characterized by a 200 -m-thick granite cataclasite, which exhibits a clear decrease in grain size and increase in microfracture density as the fault surface is approached. Undulatory extinction in quartz and feldspar and abundant quartz deformation lamellae at distances more than $\mathbf{2 0 0} \mathbf{~ m}$ from the fault surface are interpreted as related to cooling of the Miocene granite rather than to normal faulting. Although mylonitic textures have previously been described in the granite, we found no evidence for mylonitization in the footwall rocks. The hanging wall of the detachment is characterized by $9 \mathrm{~m}$ of deformed, partially dolomitized limestone, with a 2-m-thick carbonate mylonite at the con-

*E-mail: manders@1deo.columbia.edu.

Present address: Paradigm Geophysics, 1200 Smith Street, Suite 2100, Houston, Texas 77002, USA. tact. Deformation features include dynamic recrystallization, grain-size reduction, development of twinning with a strong preferred orientation, some grain-size layering, and undulatory extinction close to the fault. Static recrystallization overprints fossils and ooids at distances greater than $9 \mathrm{~m}$.

Drill cuttings and some core recovered at similar distances above and below the hypothesized Sevier Desert detachment show no evidence for localized deformation (ARCO Hole-in-the-Rock No. 1, ARCO Meadow Federal No. 1, and Argonaut Energy Federal No. 1 wells). Fossils and ooids are undeformed in Paleozoic carbonate rocks within $3 \mathrm{~m}$ below the contact, and sandstone and conglomerate with rounded clasts lacking more than background levels of microfracturing are found in samples within $3 \mathrm{~m}$ above the contact. These features contrast markedly with those of the Cave Canyon detachment, which was active at a considerably shallower and cooler level in the crust $\left(\sim 5 \mathrm{~km}\right.$ and $\left.<300{ }^{\circ} \mathrm{C}\right)$ than is implied for Paleozoic rocks beneath the Sevier Desert, once hanging-wall rocks are restored along the hypothesized detachment (9-14 km and $280-425{ }^{\circ} \mathrm{C}$ at the locations studied). The very different character of the two surfaces reinforces our earlier suggestion that beneath much of the Sevier Desert basin, the base of the Tertiary section is an unconformity rather than a low-angle normal fault.

Keywords: brittle rock deformation, fault zones, normal faults, Sevier Desert, Utah.

\section{INTRODUCTION}

Outcrop studies and seismic reflection profiles acquired by the petroleum industry in the western United States (e.g., Armstrong, 1972; Wright and Troxel, 1973; Royse et al., 1975; McDonald, 1976) led in the late 1970s to the emergence of the idea that normal faults can move in the brittle crust at dips lower than expected from classical fault mechanics (Anderson, 1942; Crittenden et al., 1980; Wernicke, 1981; Armstrong, 1982). Since then, geologists have interpreted a variety of contacts worldwide, in both continental and oceanic settings, as low-angle normal faults (see Wernicke, 1995). However, the absence of unequivocal evidence for large earthquakes on such faults (e.g., aftershock, geodetic or surface rupturing data requiring a low-angle solution; cf. Abers, 1991; Wernicke, 1995) continues to present a paradox that deserves further attention.

One of the earliest and most influential reported examples of an upper crustal low-angle normal fault is beneath the Sevier Desert in west-central Utah (Fig. 1), and is generally referred to as the Sevier Desert detachment (e.g., Allmendinger et al., 1983; Von Tish et al., 1985). This feature has long figured prominently in the development of models for crustal extension because its large scale, apparently planar geometry in dip profile, and relative youth imply that, if it is a fault, it must have moved with an inclination not much different from its present $11^{\circ}$ (e.g., Wernicke and Burchfiel, 1982; Wernicke, 1985). However, the imaged surface cannot be studied in out-

GSA Bulletin; July 2001; v. 113; no. 7; p. 895-907; 8 figures. 


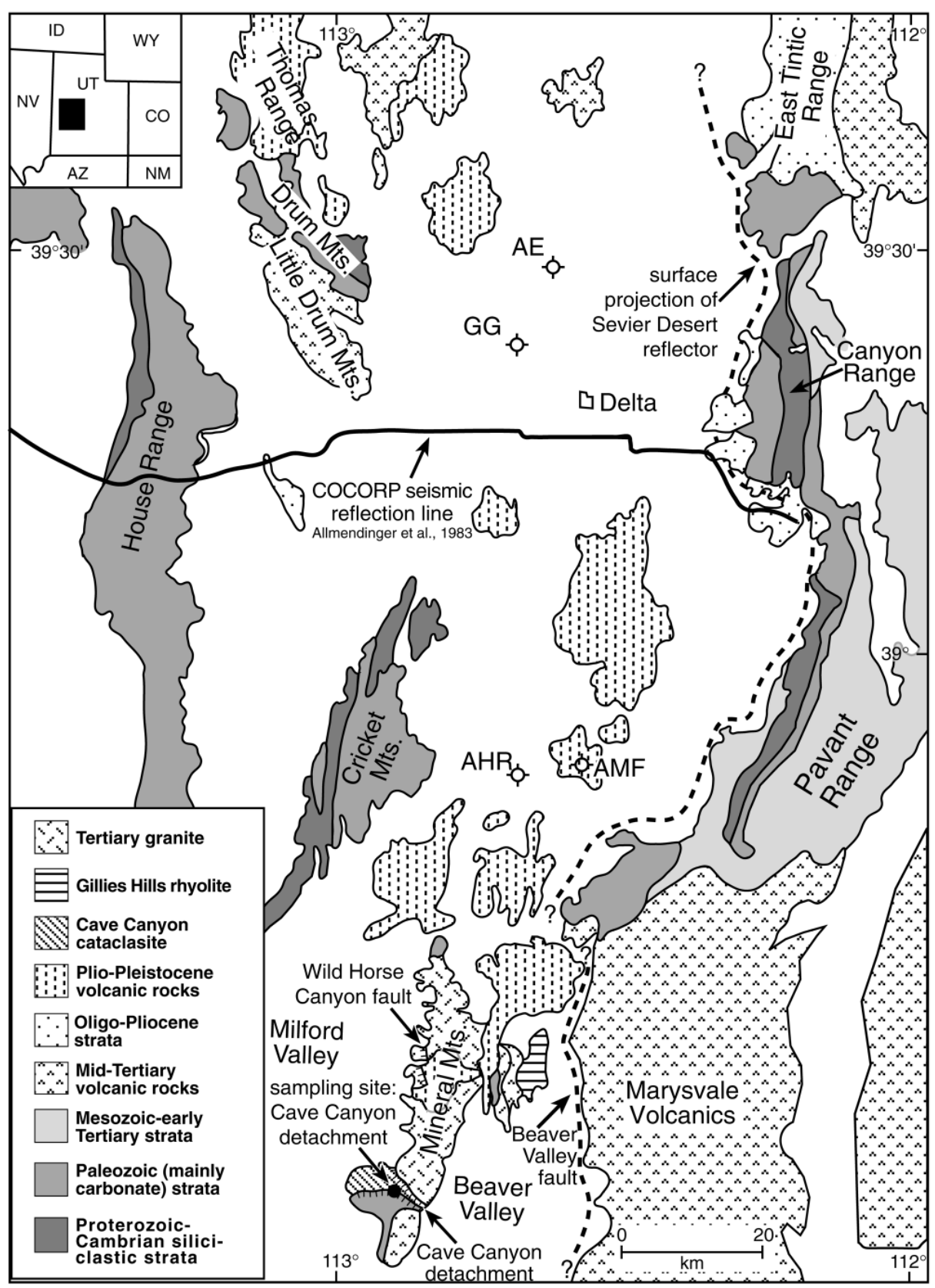

Figure 1. Generalized geological map of Sevier Desert basin and Mineral Mountains area, Utah (modified from Von Tish et al., 1985; Coleman and Walker, 1992). Abbreviations for wells: AE-Argonaut Energy Federal No. 1; AHR-ARCO Hole-in-the-Rock No. 1; AMF-ARCO Meadow Federal No. 1; GG-Gulf Gronning No. 1. Dashed line shows projected surface location of hypothesized west-dipping Sevier Desert detachment and Beaver Valley fault.

crop (cf. Otton, 1995), and borehole cuttings from the inferred hanging-wall block yield no evidence for the anticipated fault-related deformation (Anders and Christie-Blick, 1994).

In this paper we compare previously published data and additional observations from both below and above the presumed detachment beneath the Sevier Desert with data obtained in pected along a low-angle normal fault with many kilometers of displacement, and casts additional doubt on the detachment interpretation for the surface beneath the Sevier Desert basin.

\section{PRIOR WORK}

The interpreted detachment beneath the Sevier Desert basin (Fig. 1) corresponds with a prominent reflection that is apparently traceable to midcrustal depths (McDonald, 1976; Allmendinger et al., 1983; Von Tish et al., 1985; Mitchell and McDonald, 1987). Well penetrations show that the reflection is related to a pronounced contrast in acoustic impedance between Tertiary clastic sedimentary rocks and underlying Paleozoic carbonate rocks (Mitchell, 1979; Mitchell and McDonald, 1987; Anders and Christie-Blick, 1994). The detachment interpretation is based primarily on the presence in seismic reflection profiles of high-angle normal faults that offset the Tertiary sedimentary rocks and sole into the low-angle surface (McDonald, 1976; Allmendinger et al., 1983; Von Tish et al., 1985; Coogan and DeCelles, 1996), an arrangement that has been attributed by some authors to backsliding on the Cretaceous Pavant thrust. Reconstructions of preextensional thrust geometry within the Sevier orogen suggest normal-sense offset on the detachment of as much as 38-40 km (Von Tish et al., 1985; Allmendinger, 1992; Royse, 1993; DeCelles et al., 1995; Coogan and DeCelles, 1996). Faulting is inferred to have begun at 26-28 Ma on the basis of fission-track and pollen dating of samples from the Gulf Gronning No. 1 well (GG in Fig. 1; Lindsey et al., 1981). The samples were interpreted to correspond with a set of dipping reflections inferred to represent originally horizontal fluvial and lacustrine strata tilted during displacement along the detachment (Von Tish et al., 1985).

South of the Sevier Desert, a similar structural depression is bounded on the east by the Beaver Valley fault (Fig. 1). This fault does not connect directly in map view to a fault at the west flank of the Pavant Range to the northeast, inferred by Planke and Smith (1991) to represent the surface expression of the Sevier Desert detachment. However, the continuity of respective footwalls suggests that the two faults may be part of the same active normal fault system. If the Sevier Desert detachment exists, the Beaver Valley fault is a plausible southern continuation of it (Coleman, 1991; Coleman et al., 1997).

The Cave Canyon detachment is located in the Mineral Mountains, within the hanging wall of the Beaver Valley fault (Fig. 1; Nielson et al., 1986). The detachment dips at $20^{\circ}$ 

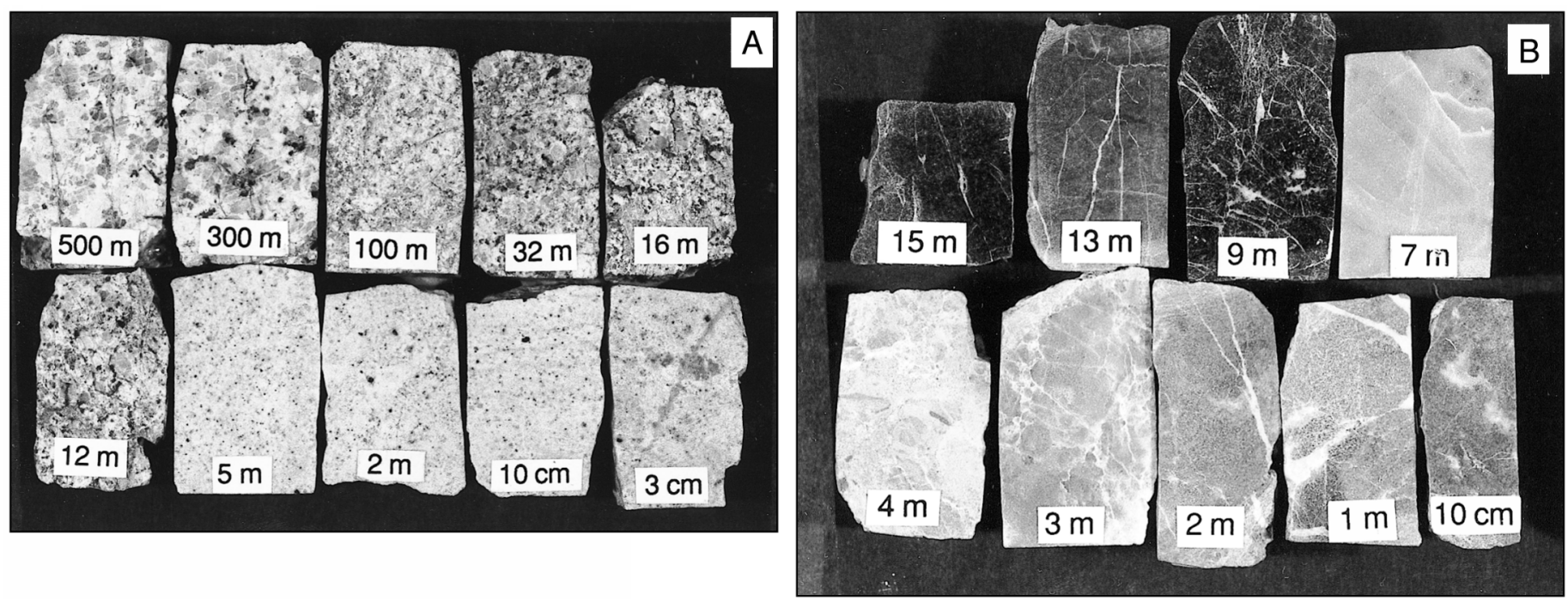

Figure 2. Polished blocks (standard thin-section size) from profile across Cave Canyon detachment, Mineral Mountains, arranged according to sampling distance from fault surface. (A) Samples from footwall granite (Miocene). (B) Samples from partially dolomitized limestone (upper Paleozoic) of hanging wall.

to the west on the western side of the range, and is associated with a 200 -m-thick cataclasite, composed largely of footwall granite of Miocene age ( $\mathrm{U}-\mathrm{Pb}$ zircon age of ca. $18 \mathrm{Ma}$; Coleman, 1991). The hanging wall consists of upper Paleozoic carbonate and Mesozoic clastic rocks (Nielson et al., 1986; Coleman et al., 1997). Seismic reflection data published by Smith and Bruhn (1984) and by Barker (1986) from the northern Mineral Mountains and adjacent Milford Valley (Fig. 1) provide support for the idea that the Cave Canyon detachment merges at depth with the Beaver Valley fault (Coleman and Walker, 1994). According to Coleman et al. (1997), the detachment is one of a series of normal faults that accommodated between 11 and $40 \mathrm{~km}$ of east-west extension, a range of estimates consistent with the amount of extension inferred to the north across the Sevier Desert.

The detachment interpretation for the prominent seismic reflection beneath the Sevier Desert was challenged by Hamilton (1994) and Anders and Christie-Blick (1994). The objections of Hamilton (1994) are based on differences in structural style compared with other well-known listric normal faults and metamorphic core complexes, on details of local geology, and on the lack of any observed seismicity along modern low-angle normal faults. Hamilton regarded the Sevier Desert reflection as a fortuitous combination of unconformities and older, Sevier-aged thrusts. Anders and Christie-Blick (1994) objected to the detachment interpretation on the rather narrower grounds that Tertiary sedimentary rocks re- covered from immediately above the purported fault surface fail to show the signs of localized microstructural damage characteristic of outcrop examples of normal faults (e.g., Anders and Wiltschko, 1994). Anders and Christie-Blick (1994) suggested on this basis that the hypothesized detachment might be better regarded as an unconformity, and that the downward termination of high-angle normal faults might be due to salt movement within the basin (see Mitchell, 1979).

Pertinent to this interpretation is the issue of whether the apparent fanning of seismic reflections observed on several industry and COCORP profiles in the northern part of the basin is due to fault growth (Von Tish et al., 1985; Coogan and DeCelles, 1996) or to the presence of multiples associated with gently tilted Miocene to Pliocene basalt layers in the upper part of the basin fill (Anders et al., 1998). The second interpretation is supported by apparently nearly horizontal layering in sedimentary rocks recovered in core from the depth of the dipping reflections, providing that there was no significant deviation of the borehole from vertical at the depth of the core. If the apparent fanning of seismic reflections is not due to fault growth, the age of the inferred detachment becomes essentially undefined even if a fault exists. Anders et al. (1998) also showed that Von Tish et al. (1985) had underestimated the seismic velocity within the Tertiary strata, and hence that the oldest sedimentary rocks in the basin predate the samples dated by Lindsey et al. (1981) and used by Von Tish et al. to define the age of the in- terpreted detachment as younger than 26-28 Ma.

\section{FOOTWALL ROCKS OF THE CAVE CANYON DETACHMENT}

Mining activity on the western flank of the Mineral Mountains has provided excellent exposure of the Cave Canyon detachment. We collected a representative suite of samples from near the location shown in Figure 4 of Nielson et al. (1986), where their line of crosssection C-C' crosses the fault. Samples were collected from the footwall granite at distances of as much as $500 \mathrm{~m}$ below fault surface; sampling was at closer spacing as the fault was approached. Representative examples are shown in Figure 2.

Visual inspection of footwall samples obtained at a distance of more than $200 \mathrm{~m}$ from the fault zone reveals little evidence for deformation (Fig. 2A). However, a different picture emerges from the examination of thin sections. At a distance of $500 \mathrm{~m}$, all quartz and feldspar grains contain healed microfractures (Fig. 3A), and many show undulatory extinction and transgranular irregular cracks (commonly filled with hematite). These features are taken to represent background deformation, although they are more abundant than observed in prior studies of fault zones (see Anders and Wiltschko, 1994). These microfractures are not expected in a young granite subject to only the modest deviatoric stresses associated with extension, but they could have a nontectonic overprint related to thermal 
cracking. Within $300 \mathrm{~m}$ of the fault, most quartz and feldspar grains exhibit undulatory extinction, and at $200 \mathrm{~m}$, a small fraction (typically $<2 \%$ ) of the rock consists of partially chloritized broken or cataclastic material. A single sample at the same distance exhibits more widespread grain-size reduction (5\%$10 \%$ ), and contains $\sim 10 \%$ chlorite. About half of the quartz grains observed at $300 \mathrm{~m}$ also show faint but unmistakable deformation lamellae, another feature not generally associated with normal faulting at shallow depth. However, if the maximum stress applied to these samples was lithostatic, the development of deformation lamellae in quartz is consistent with hornblende barometric data of Coleman (1991), which indicates a crystallization depth for the Mineral Mountains batholith of 28.5-9 km (see Drury, 1993). At $100 \mathrm{~m}$ from the fault, $\sim 40 \%-50 \%$ of the samples consist of broken material, although the rock is well indurated, as is the case for all samples examined in this study. Hand specimens at $100 \mathrm{~m}$ show clear evidence for grain-size reduction (Fig. 2A).

At $56 \mathrm{~m}$, cataclastic zones subdivide the rock into islands of intact grains. Within the islands, feldspars exhibit a pronounced intergrowth with quartz (granophyric texture), with more poorly resolved regions that may be myrmekitic. Samples from the interval between 44 and $12 \mathrm{~m}$ display few qualitative differences. All contain islands of intact protolith granite with intense microfracturing and undulatory extinction, surrounded by diffuse zones of both brecciated and rounded clasts of broken grains (Fig. 3B).

The character of the rock changes markedly at $5 \mathrm{~m}$ below the fault, at both outcrop and thin-section scales. Island structures disappear, and there is a marked reduction in grain size. No original grain is larger than $0.5 \mathrm{~mm}$, and the average is between 0.2 and $0.3 \mathrm{~mm}$ (Fig. $3 \mathrm{C})$. Sericite alteration dominates in thin sections, making it difficult to observe deformational features. However, two generations of quartz veins can be resolved. These generations can also be seen in samples collected at $2 \mathrm{~m}, 10 \mathrm{~cm}$, and $3 \mathrm{~cm}$ from the fault. One is a pattern of interlocking quartz grains $\sim 0.1$ $\mathrm{mm}$ in diameter, with sharp contacts and triple-point intersections. The other is manifested as veins of fine-grained interlocking quartz. In a sample taken at $3 \mathrm{~cm}$, a small vein $(0.5$ $\mathrm{mm})$ cuts a larger one $(\sim 2 \mathrm{~mm})$, and has a significantly lower microfracture density than the larger vein, clearly indicating that the veins grew sequentially during the faulting.

\section{Microfracture Analysis}

Microfracturing is often thought to be associated with development of process zones around developing faults (Scholz et al., 1993), and several fault-zone studies have revealed an inverse relationship between microfracture density and distance from the fault (Engelder, 1974; Brock and Engelder, 1977; Anders and Wiltschko, 1994; Vermilye, 1996; Vermilye and Scholz, 1998). This inverse relationship is apparent in footwall rocks close to the Cave Canyon detachment (Fig. 4). However, in contrast to results presented by Anders and Wiltschko (1994), Vermilye (1996), and Vermilye and Scholz (1998), microfracture data from the Cave Canyon detachment do not exhibit a clear logarithmic decrease in density with increasing distance from the fault surface. Instead, microfracture density increases toward the fault in a series of jumps or plateaus.

Four plateaus are recognized. The first is identified by a jump from a background density of 7.2 microfractures $/ \mathrm{mm}$ at $500 \mathrm{~m}$ to between 20.0 and 15.9 microfractures $/ \mathrm{mm}$ at 200 $\mathrm{m}$ and $300 \mathrm{~m}$, respectively. The next plateau is represented by a microfracture density in the low and middle 30s between 100 and 16 $\mathrm{m}$ from the fault. Between 12 and $2 \mathrm{~m}$ below the fault, the density is in the middle and low 50s. The two highest densities, 62.6 microfractures $/ \mathrm{mm}$ and 63.2 microfractures $/ \mathrm{mm}$, are found in the two samples obtained closest to the fault $(10 \mathrm{~cm}$ and $3 \mathrm{~cm}$, respectively). A similar pattern was identified near thrust faults by Wojtal and Mitra (1986), who suggested that such plateaus are the result of increasing resistance to fracture for grains with smaller diameter.

Within about $5 \mathrm{~m}$ beneath the Cave Canyon detachment, small grains are intensely microfractured (Fig. 3D), although a coating of clay makes it difficult to assess microfracture density, and leads to large counting errors in samples close to the fault contact (Fig. 4). The same samples contain clear evidence for late or last stage quartz growth. Large grains of clear quartz lack microfractures, and they have round borders with radiating fibrous halos of uncertain composition (possibly sericite; Fig. 3D). Although they make up only 5\%-10\% of the total grains, they are more than 10 times as large as microfractured grains. In their description of the same rocks, Nielson et al. (1986) referred to the presence of "quartz augen" in a granite mylonite, a misinterpretation, we suspect, of the same features. Nielson et al. did not mention whether stronger and more abundant feldspar forms augen. We did not recognize any augen, and found no evidence for mylonite development in footwall rocks, although we did observe mylonitization in the $2 \mathrm{~m}$ of carbonate rock immediately above the detachment.

\section{HANGING-WALL ROCKS OF THE CAVE CANYON DETACHMENT}

In the area studied, the hanging wall of the Cave Canyon detachment consists of upper Paleozoic carbonate rocks. These were sampled only to a distance of $15 \mathrm{~m}$ from the fault, because at distances greater than this, no macroscopic changes in the character of the rock were observed. Nielson et al. (1986) also noted that the zone of deformation is significantly narrower in the hanging-wall block than in the footwall. Thin-section analysis of 11 samples at distances from $15 \mathrm{~m}$ to $3 \mathrm{~cm}$ confirmed the relative thinness of the upper plate deformation zone.

Samples taken at $15 \mathrm{~m}$ contain abundant undeformed ooids and fossil fragments (Fig. $5 \mathrm{~A}$ ), although with a clear pattern of new calcite grain growth, a unimodal size distribution, and an average size ranging from 80 to 300 $\mu \mathrm{m}$. Also present are minor cracks with small offset, some filled with clear to white calcite that contrasts with the dark gray partially dolomitized limestone matrix (Fig. 2B). At $9 \mathrm{~m}$ from the fault, fossils are difficult to recognize, but the grain-size distribution is still unimodal with a range of 100 to $200 \mu \mathrm{m}$. The sample is traversed by a number of parallel fractures, and characterized by twinning with a crude preferred orientation (Fig. 5B). The most significant changes are noted between 9 $\mathrm{m}$ and $7 \mathrm{~m}$, where there is a marked change in the color of the carbonate from dark gray to light gray, a characteristic that persists in all samples within $7 \mathrm{~m}$ of the fault (Fig. 2B). No fossils or ooids are preserved in the samples at $7 \mathrm{~m}$, and these samples also exhibit a significant decrease in calcite grain size (to between 40 and $100 \mu \mathrm{m})$.

At $5 \mathrm{~m}$ from the fault, the grain size is further reduced to between 15 and $20 \mu \mathrm{m}$. Only a small fraction of the grains are observed in a standard petrographic microscope as having twins at distances of $5 \mathrm{~m}$ or more from the fault. At $4 \mathrm{~m}$ the trend in reduction of mean grain size reverses itself. Instead, grain size is bimodally distributed. The larger grains $(200-250 \mu \mathrm{m})$ tend to exhibit undulatory extinction and twinning, while the smaller grains $(40-80 \mu \mathrm{m})$ do not. Calcite twins at this distance exhibit a strong preferred orientation.

At $2 \mathrm{~m}$ (Fig. 5C), the carbonate rocks begin to show evidence of dynamic recrystallization. 

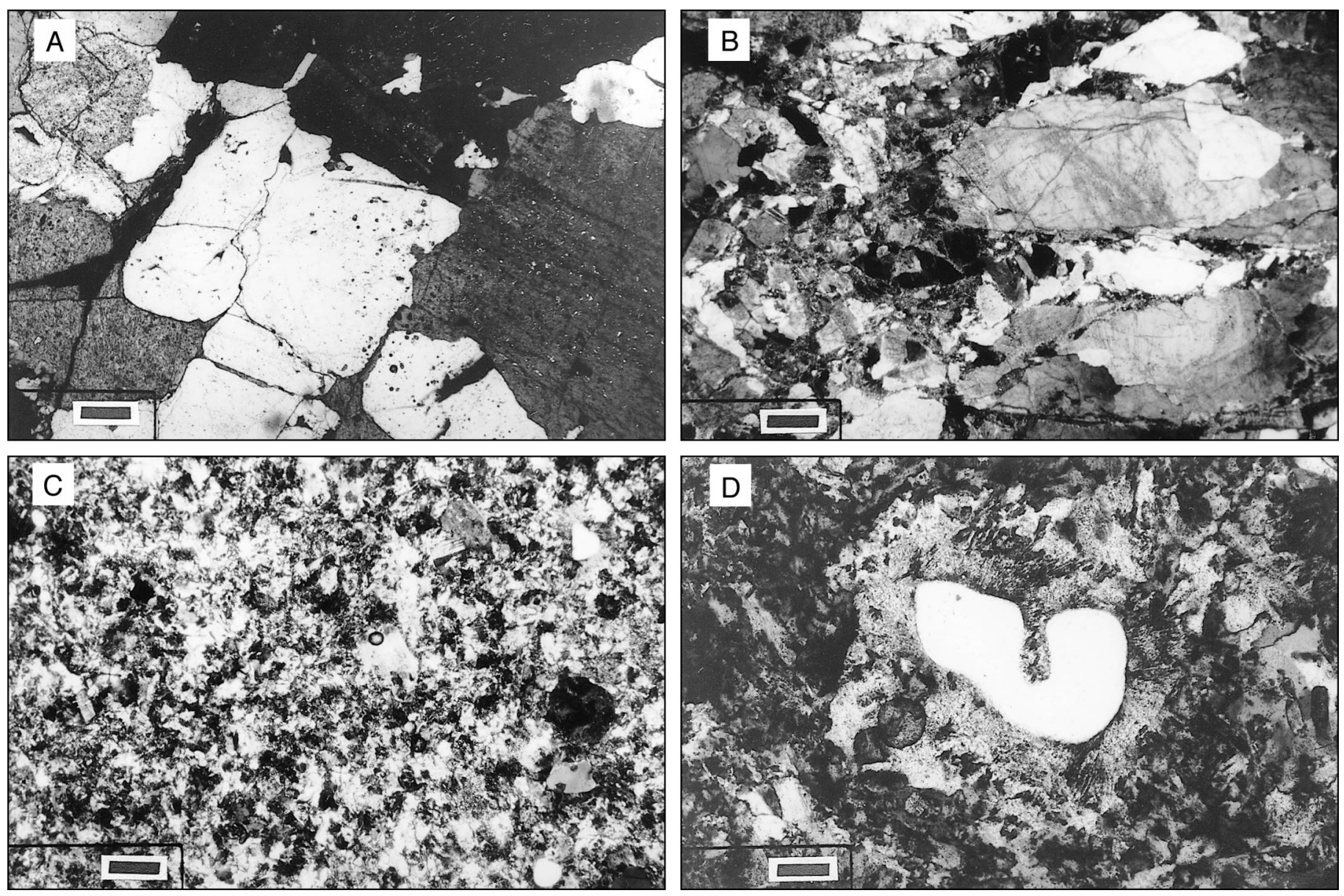

Figure 3. Photomicrographs from footwall of Cave Canyon detachment. Scale bar is $0.4 \mathrm{~mm}$ in A to C, and $0.8 \mathrm{~mm}$ in D. (A) Littledeformed granite, $500 \mathrm{~m}$ below fault contact. Fluid-inclusion trails correspond with individual microfractures. (B) Sample $12 \mathrm{~m}$ below fault contact. This example is typical of samples between 12 and $44 \mathrm{~m}$ from the fault. The percentage of intact islands seen in this photomicrograph is greatly reduced from $100 \mathrm{~m}$ below the contact where islands first become prominent. Grains within surviving islands become intensely microfractured and crisscrossed by hematite-filled veins. (C) Sample typical of those from between 5 and $2 \mathrm{~m}$ below fault. The island structure has disappeared, leaving shattered and broken grains. The grain size is greatly decreased from that of protolith at $500 \mathrm{~m}$. (D) Sample from $10 \mathrm{~cm}$ below fault. Large second-stage quartz grain with halo of sericite (?). Embayment indicates grain growth at expense of matrix.

The mean grain size in the bimodal population ranges from 250 to $300 \mu \mathrm{m}$ for the large crystals and from 60 to $90 \mu \mathrm{m}$ for smaller ones. About $30 \%$ of the grains at $2 \mathrm{~m}$ exhibit lobate boundaries (cf. Fig. 12B of Urai et al., 1986), which we interpret to indicate grain boundary migration as an integral component of dynamic recrystallization. Our observation of the carbonate rock at $2 \mathrm{~m}$ is similar to Burkhard's (1993) type III twinning, which he interpreted as forming at temperatures $>200{ }^{\circ} \mathrm{C}$. Also at $2 \mathrm{~m}$ from the fault, almost all large calcite grains exhibit undulatory extinction (Fig. 5C).

At $10 \mathrm{~cm}$ from the fault, the sample is dominated by lobate grains (Fig. 5D), and only rare grains, usually the smallest, are untwinned. The grain size is variable, but generally bimodal, with one mode in the
200-250 $\mu \mathrm{m}$ range, and the other in the $20-40 \mu \mathrm{m}$ range. Also at $10 \mathrm{~cm}$ from the fault, there is a strong preferred orientation to the calcite twins and a faint segregation of grain sizes approximately parallel to twin orientation. The twins, especially in the larger grains, are $2-5 \mu \mathrm{m}$ wide (Fig. 5D), significantly wider than any twin observed in samples more than $4 \mathrm{~m}$ above the fault. The observed twins are similar to the type IV twins of Burkhard (1993). At this distance, there is clear evidence for dynamic recrystallization.

In general, the pattern of grain-size reduction observed between 15 and $5 \mathrm{~m}$ from the fault zone resembles that described by Newman and Mitra (1994) along the Pioneer Landing thrust in the Mountain City window of Tennessee. Thin sections from their traverse of the fault, which has a total displacement of $\sim 100 \mathrm{~m}$, are similar to our suite of samples from the Cave Canyon detachment from 15 to $5 \mathrm{~m}$ above the fault. However, the samples observed by Newman and Mitra (1994) show a progressive decrease in grain size, whereas those from the Cave Canyon detachment show a reverse trend toward larger grain sizes within $5 \mathrm{~m}$ of the fault. The difference could be due to our examining partially dolomitized limestones, in contrast to the dolomites studied by Newman and Mitra. Newman and Mitra (1994) suggested that the grain-size reduction they observed is due in part to the presence of water, and that the Pioneer Landing thrust moved at a temperature of $270{ }^{\circ} \mathrm{C}$ (based on assumed geothermal gradient) in what they thought should be the brittle field. 


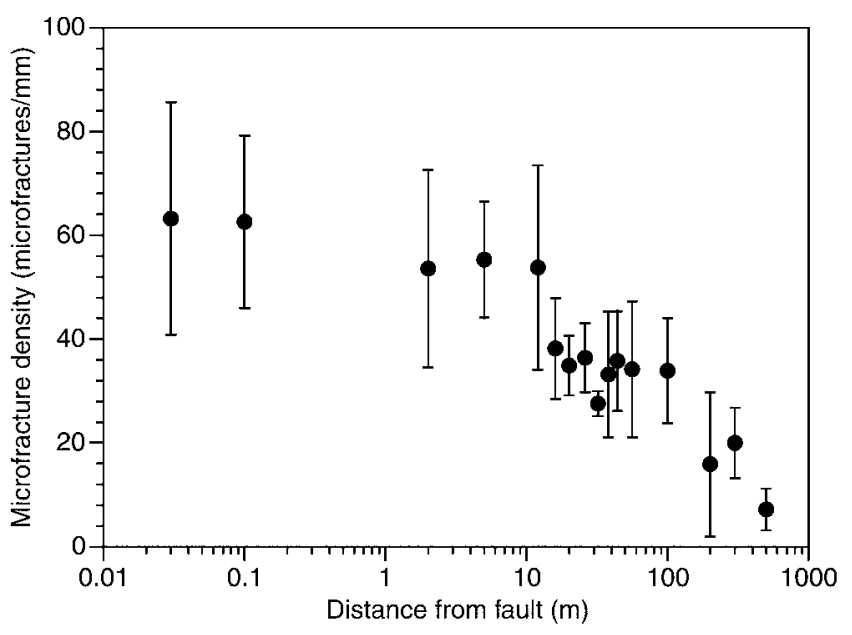

Figure 4. Graph of microfracture density versus distance below Cave Canyon detachment. All measurements were made on quartz grains in footwall granite. Microfracture density was determined by counting number of microfractures that intersect a randomly placed $0.5 \mathrm{~mm}$ line. An objective lens with $20 \times$ magnification and numerical aperture of 0.40 was used for all measurements, along with an ocular lens with $10 \times$ magnification. Second-stage grains in samples at $5 \mathrm{~m}$ to $10 \mathrm{~cm}$ were excluded. Microfracture values are based on 15 measurements of microfractures per thin section. Error bars indicate one standard deviation.

However, their study showed that dynamic recrystallization was clearly active at these low temperatures, and that at shallow, and presumably low temperatures, carbonate rocks near a fault surface can and do behave in a ductile manner.

\section{CORRELATION BETWEEN TERTIARY-PALEOZOIC CONTACT AND SEVIER DESERT REFLECTION}

Existing publications on the Sevier Desert are unanimous in placing the inferred detachment (Sevier Desert reflection) at the contact between the Tertiary basin fill and underlying Paleozoic carbonate rocks (McDonald, 1976; Allmendinger et al., 1983; Von Tish et al., 1985; Mitchell and McDonald, 1987; Planke and Smith, 1991; Coogan and DeCelles, 1996; Wills, 2000). Several petroleum exploration wells penetrate this surface (Fig. 1). Three of them, the ARCO Hole-in-the-Rock No. 1 (AHR), the ARCO Meadow Federal No. 1 (AMF), and the Argonaut Energy Federal No. 1 (AE), are located directly on seismic reflection profiles, and provide unambiguous ties between the Sevier Desert reflection, a marked increase in acoustic impedance (sonic velocity times density) responsible for the reflection, and cuttings containing evidence for the location of the Tertiary-Paleozoic contact. (See Fig. 6 for the seismic tie at the AHR well, and Fig. 2 of Mitchell, 1979, for a seismic profile across the AE well. A profile across the AMF well is proprietary.) contact closely matches an abrupt increase in sonic velocity at an appropriate depth in each of the three wells studied: at $2773.6 \mathrm{~m}$ in AHR, at $2350.6 \mathrm{~m}$ in $\mathrm{AE}$, and at $1785.5 \mathrm{~m}$ in AMF. The best tie is for the AHR well. Although some carbonate is found in almost all cuttings samples from the Tertiary section in this well, angular or broken chips most likely derived from intact $\mathrm{Pa}$ leozoic stratigraphy first appear in the interval between 2776.7 and $2779.8 \mathrm{~m}$, and they are the dominant chip type between 2779.8 and 2789.5 $\mathrm{m}$, the top of a cored interval described below. A slight discrepancy between depths inferred from logs and cuttings, in this case 3.0 to 6.1 $\mathrm{m}$, is expected owing to the need to make a correction for the time taken for cuttings to travel up the borehole. At the AE well, carbonate rocks first appear abundantly in cuttings at a depth of $2357.3 \mathrm{~m}$ (Mitchell, 1979). Most of the sonic log above depth of $2346.9 \mathrm{~m}$ is missing, which means that velocity data are available for only $10.4 \mathrm{~m}$ of the Tertiary section before the Paleozoic stratigraphy is encountered. At the AMF well, the Tertiary-Paleozoic contact is located on the basis of carbonate and shale cuttings at a depth of between 1773.9 and 1777.0 $\mathrm{m}$, slightly shallower than previously interpreted (1777.0-1780.0 m; Anders and Christie-Blick 1994), and 8.5-11.6 m shallower than the depth suggested by a marked increase in sonic velocity and change in sonic character (from variable to smooth). In this case, the apparent discrepancy is likely due to the interbedding of carbonate
The inferred position of the Tertiary-Paleozoic with shale in the upper part of the Paleozoic section. Uncertainties in the depth of the Tertiary-Paleozoic contact are well below seismic resolution at each borehole.

\section{PALEOZOIC ROCKS BENEATH THE SEVIER DESERT REFLECTION}

Several thousand cuttings of carbonate rock obtained from the three wells (AHR, AMF, and $\mathrm{AE}$ ), along with $5.5 \mathrm{~m}$ of core from the upper part of the Paleozoic section in the AHR well, show no evidence for the dynamic recrystallization or other indications of ductile or incipient ductile deformation that might be expected in the detachment interpretation. Fossils, fossil fragments, and ooids are undeformed. The character of the carbonate rocks does not vary as a function of distance from the Tertiary-Paleozoic contact in any of the wells studied.

\section{ARCO Hole-in-the-Rock No. 1 (AHR) Well}

Some of the most important evidence is that provided by core recovered from the interval between 2789.5 and $2795.0 \mathrm{~m}, \sim 12.8 \mathrm{~m}$ below the top of the Paleozoic section in the AHR well. The core consists of fossiliferous nodular wackestone of a sort commonly observed in strata of Cambrian age in the region (Fig. 7). Thin sections reveal abundant undeformed trilobite fragments, including cephalons (Fig. 8D), in both light gray nodular layers and dark gray, more clay-rich, wackestone between those layers. The same rock types are observed in cuttings from the upper part of the Paleozoic section at the AHR well (2776.7-2789.5 m). Pyritiferous wackestone with lath-shaped fossil fragments to $60 \mu \mathrm{m}$ long dispersed in micrite (grain size $\sim 8$ $\mu \mathrm{m})$ closely resembles the nodular layers observed in the core. Somewhat coarser grained partially dolomitized limestone (grain size $\sim 40$ $\mu \mathrm{m})$ with abundant clay wisps no more than a few microns thick is lithologically identical to the dark gray layers.

\section{ARCO Meadow Federal No. 1 (AMF) Well}

The Tertiary-Paleozoic contact in the AMF well is defined by the first appearance of dolomitized limestone containing abundant ooids. This limestone, described by L.F. Hintze (2000, personal commun.) as the Cambrian Orr Formation, is recrystallized, with individual crystals averaging between 15 and 30 $\mu \mathrm{m}$. Ooids are best seen in thin sections that are $\sim 100 \mu \mathrm{m}$ thick. In the first interval in which they are observed, between 1773.9 and $1777.0 \mathrm{~m}$, ooids are found in only $5 \%$ of the chips (see Kerr, 1993, for a color micrograph). 

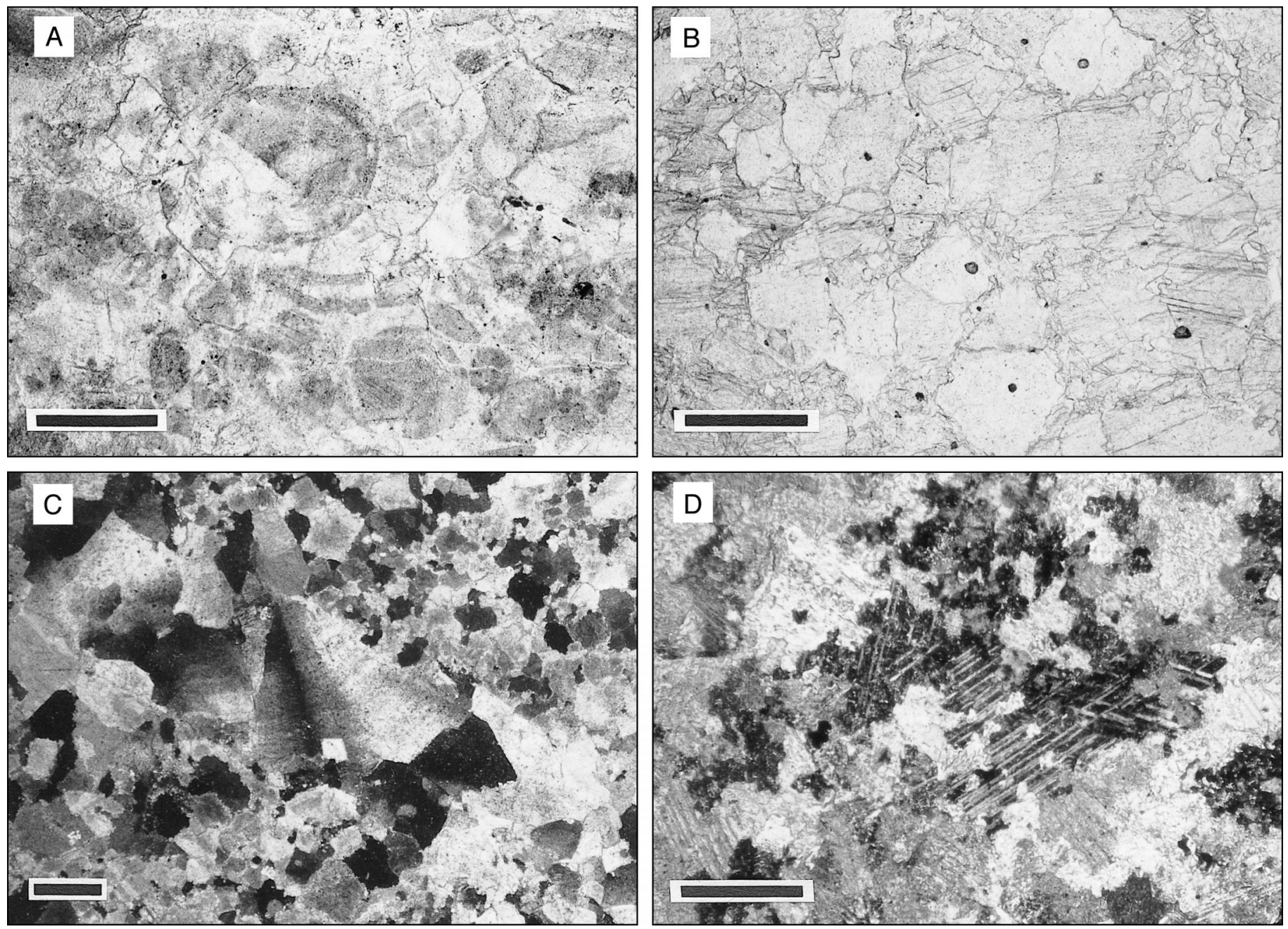

Figure 5. Photomicrographs from hanging wall of Cave Canyon detachment. All samples are from the same partially dolomitized limestone. Scale bar is $\mathbf{0 . 4} \mathbf{~ m m}$ in each case. (A) Sample from $15 \mathrm{~m}$ above the fault. Little-deformed ooids, fossils, and fossil fragments are observed. Note several fractures with minor offset, and evidence for static recrystallization. (B) Sample from $9 \mathrm{~m}$ above the fault. Note calcite twins with preferred orientation, abundant through-going fractures, and minor breakage of larger grains. (C) Sample from $\mathbf{2} \mathbf{m}$ above the fault. Undulatory extinction is present in all calcite grains. About $\mathbf{3 0} \%$ of grains exhibit lobate boundaries. Note mixture of grain sizes. (D) Sample from $10 \mathrm{~cm}$ above fault. The sample is completely recrystallized. Lobate boundaries indicate dynamic recrystallization.

In the next interval, from 1777.0 to $1780.0 \mathrm{~m}$, chips with ooids constitute $25 \%$ of the total. The ooids average a little less than $0.5 \mathrm{~mm}$ in diameter, and are undeformed (note the random orientation of elliptical sections of ooids shown in Fig. 8A). Unrecrystallized fossil fragments are present within this same interval (Fig. 8B), including hook-shaped fragments similar to those observed in the core at the AHR well (Fig. 8D). Recrystallization of these rocks is sporadic, but where present, it tends to overprint an entire chip (equidimensional polygonal grains with sharp boundaries), and it continues to a depth of at least $2042.2 \mathrm{~m}$ in the AMF well, the deepest level at which analyses were performed. Similar re- crystallization patterns are commonly observed in Cambrian units sampled in surface outcrop in the Cricket and House Ranges to the west of the Sevier Desert (Fig. 1).

\section{Argonaut Energy Federal No. 1 (AE) Well}

The Tertiary-Paleozoic contact in the AE well is marked by a $248.7 \mathrm{~m}$ section of "white to light-gray and gray sucrosic carbonates, very finely crystalline to grainy, [with] occasional pyrite, and a few interbeds of dark-gray to black, hard, argillaceous carbonate" (Mitchell, 1979, p. 508). Mitchell described the section, which he identified as Ordovician Fish Haven Dolomite, as monotonous with lit- tle lithologic variation. We observed the same monotonous gray carbonate, but did not sample enough of the section to encounter the dark gray to black carbonate. Individual crystals are typically 5-10 $\mu \mathrm{m}$ and display no down-hole variation below the Tertiary-Paleozoic contact. No fossils were found in this borehole, consistent with the outcrop expression of the same stratigraphic unit.

\section{TERTIARY STRATA ABOVE THE SEVIER DESERT REFLECTION}

Both cuttings and core are available from Tertiary strata above the Paleozoic contact. In this case, however, relevant data come entirely 


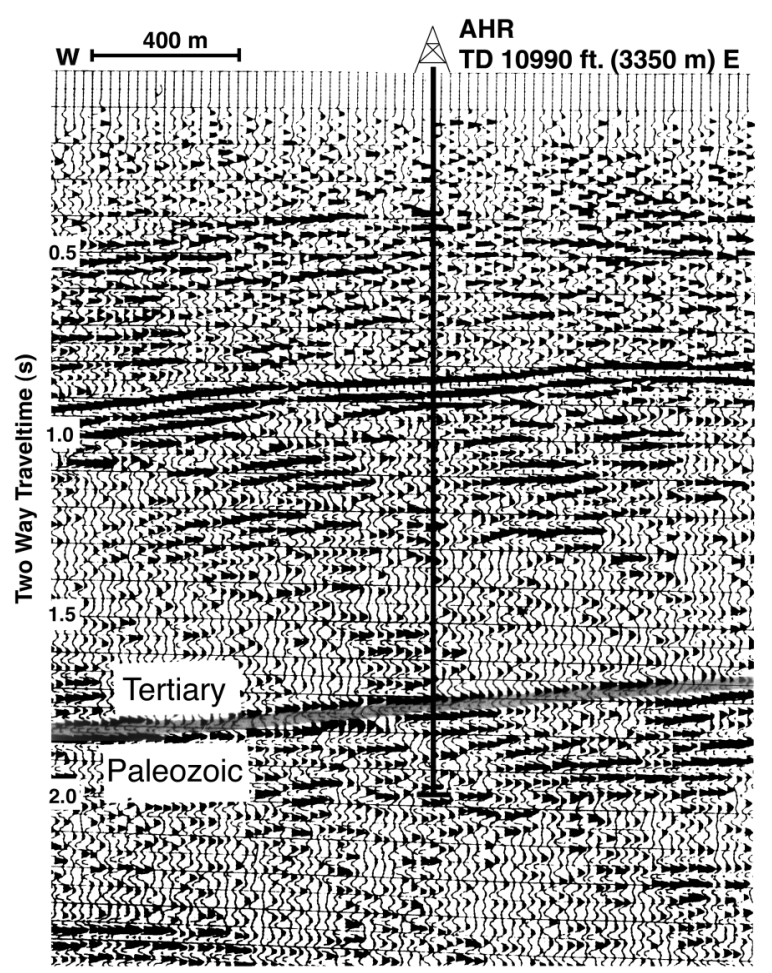

Figure 6. Seismic reflection profile across ARCO Hole-in-the-Rock No. 1 well. The Sevier Desert reflection is seismically well defined, and corresponds with contact between clastic sedimentary rocks and evaporites of Tertiary age and Paleozoic carbonate rocks (data published in Mitchell and McDonald, 1987).

from cuttings because the closest core is more than $300 \mathrm{~m}$ above the contact at the AMF well. Each $3 \mathrm{~m}$ interval provided as many as several hundred grains. These were first examined under a binocular microscope for evidence of slickenlines or other indications of fault-zone deformation. None was observed. Several thin sections, each containing 20-30 cuttings fragments, were made for $\sim 40$ intervals in the AHR and AMF wells. At the AE well, samples within several hundred meters of the contact consist predominantly of evaporite minerals, with the exception of the 9.7 $\mathrm{m}$ interval directly above the Tertiary-Paleozoic contact. It was therefore not possible to undertake a quantitative microfracture study comparable to that published by Anders and Christie-Blick (1994) for the AHR and AMF wells. The main conclusion from our study of the Tertiary deposits is that, as in the Paleozoic rocks below the contact, evidence for postdepositional deformation is lacking.

\section{ARCO Hole-in-the-Rock No. 1 (AHR) Well}

In the AHR well, sedimentary rocks within and immediately above the interval containing the Tertiary-Paleozoic contact are for the most part hematitic fine- to medium-grained sandstones and siltstones. The sandstones contain $\sim 5 \%$ volcanic lithic fragments and plagioclase crystals. These characteristics are typical of samples from all depths examined in the Tertiary section, including samples from core through interbedded sandstone, siltstone, and conglomerate at a depth of $1800.1-1805.9 \mathrm{~m}$, between 970.8 and $973.8 \mathrm{~m}$ above the contact.

Samples from close to the Tertiary-Paleozoic contact include a number of features of primary depositional origin. Of 200 chips, 3 are composed of ash-flow tuff. Each chip is rounded, with an alteration rind a few microns thick. Other rounded grains are composed of quartzite and limestone, some with rinds or, in the case of quartzite grains, coatings of calcite, hematite, or both. These rounded grains constitute only a few percent of the total in the interval containing the contact, and in the two $3 \mathrm{~m}$ intervals directly above, but $\sim 10 \%-15 \%$ of the chips in the same samples consist of rounded platelets of muscovite. About $5 \%$ of the grains are composed of evaporite minerals, and evaporite mineralization is common in sandstone chips. Mitchell and McDonald (1987) interpreted the presence of abundant evaporites in the middle part of the Tertiary section. Three volcanic chips from the lowest Tertiary samples were dated by ${ }^{39} \mathrm{Ar} /{ }^{40} \mathrm{Ar}$ and yielded Cretaceous ages.

\section{ARCO Meadow Federal No. 1 (AMF) Well}

Through much of the Tertiary section studied in the AMF well, chips are composed mostly of hematite-stained, very fine grained sandstone and siltstone $(0.08-0.01 \mathrm{~mm})$, similar in lithology to sedimentary rocks described by others from cuttings and cores throughout the Sevier Desert basin (e.g., McDonald, 1976). Sandstone chips typically contain $1 \%-3 \%$ volcanic lithic fragments or feldspar (identified on the basis of twinning).

Sedimentary rocks in the basal $15.2 \mathrm{~m}$ of the Tertiary in the AMF well are distinctly different in both grain size and composition. Below the interval between 1758.7 and 1761.7 $\mathrm{m}$, sandstones are coarser grained $(0.1-0.5$ $\mathrm{mm})$, with well-rounded particles. Volcanic grains and feldspar are absent in the several hundred individuals examined. Pore space is filled by large crystals of calcite (poikilotopic texture). The lack of deformation, the increase in grain size, and the increase in rounding observed as the contact is approached, were taken by Anders and Christie-Blick (1994) as evidence for a depositional contact. Undulatory extinction, intergrown subgrains, and dust lines (associated with overgrowths) imply a quartzite protolith, a rock type that is exposed today in the Cambrian and Proterozoic strata of several ranges around the Sevier Desert, including the Pavant Range, 10-15 km to the southeast (Fig. 1).

\section{Argonaut Energy Federal No. 1 (AE) Well}

Mitchell (1979, p. 505) reported a basal Tertiary conglomerate in the AE well as follows. "The samples in the interval from 7,702 ft $(2,347.6 \mathrm{~m})$ to $7,734 \mathrm{ft}(2,357.3 \mathrm{~m})$ are composed of rust red to pink conglomeratic debris in a clay matrix. The conglomerate contains quartz pebbles, carbonate pebbles, and rounded dark volcanic debris." This description bears a strong resemblance to the rock types we observed in the conglomerates in cores from higher in the stratigraphic section of both the AHR well and the Gulf Gronning No. 1 core. Although our pick for the Tertiary-Paleozoic contact in the $\mathrm{AE}$ well is in the interval between 2350 and $2353 \mathrm{~m}$, the samples described by Mitchell (1979) are clearly conglomerate, with a great variety of clast types: ash-flow tuff, andesite, quartzite, siltstone, and several varieties of carbonate rock. As illustrated in Figure 8C, most of the nonevaporitic 
particles are well rounded, consistent with fluvial transport and deposition. The surfaces of many grains are partly smooth and partly angular, as if broken from originally larger particles. Many carbonate grains examined in thin section exhibit alteration rinds. Quartzite grains are partially coated with calcite cement and, at small circular dimples (possibly granule and pebble contact points), with hematite. Close examination of these samples provides no support for the interpretation of a fault breccia (cf. Coogan and DeCelles, 1996).

\section{Microfracture Analysis}

A previously published study of microfractures in the AHR and AMF wells (Anders and Christie-Blick, 1994), similar to that described here for the Cave Canyon detachment, indicated that there is no significant change in microfracture density as the Tertiary-Paleozoic contact is approached. Microfracture density actually decreases downward. Cursory examination of grains in the basal conglomerate of the $\mathrm{AE}$ well reveals a comparable background level of microfracturing.

\section{COMPARISON OF CAVE CANYON DETACHMENT AND THE HYPOTHESIZED SEVIER DESERT DETACHMENT}

Two significant conclusions can be drawn from our observations in the Mineral Mountains and Sevier Desert. First, the deformational features that we have documented show that the Cave Canyon detachment is a seismically cycled normal fault with a well-developed fault zone. Second, rocks close to the Tertiary-Paleozoic contact beneath the Sevier Desert are essentially undeformed at all locations examined. The marked contrasts between these surfaces cast doubt on the existence of a detachment beneath the Sevier Desert, and on the hypothesis that the Cave Canyon detachment is a hanging-wall splay of such a fault. The Sevier Desert detachment would have developed at a significantly greater depth than is implied by observations at the Cave Canyon detachment, and both ductile and brittle characteristics should be well developed.

\section{Pressure-Temperature Conditions at Cave Canyon Detachment}

Available evidence suggests that deformation along the Cave Canyon detachment took place at a depth of $<5 \mathrm{~km}$, and at a temperature of $<300{ }^{\circ} \mathrm{C}$. The maximum depth of faulting is restricted by the depth of crystal-

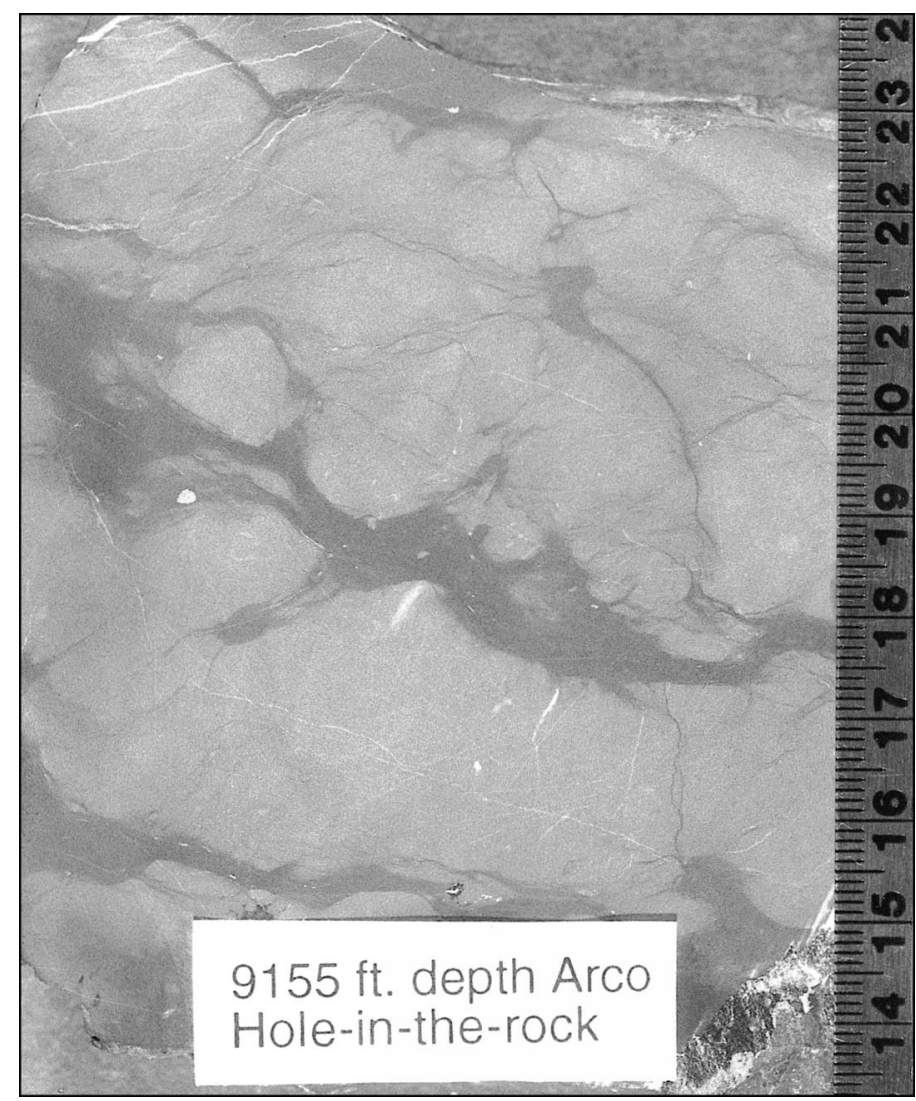

Figure 7. Photograph of core of nodular wackestone recovered from $9155 \mathrm{ft}$. $(2790.6 \mathrm{~m})$, $13.9 \mathrm{~m}$ below the Tertiary-Paleozoic contact in the ARCO Hole-in-the-Rock No. 1 well. Width of core is $11 \mathrm{~cm}$.

lization of the granitic batholith that makes up the entire exposed footwall of the detachment. Hornblende barometry studies (Coleman, 1991) suggest that the batholith was intruded at $2.4 \pm 0.5$ kilobar, or $\sim 8.6 \pm 1.9 \mathrm{~km}$ depth. Although no piercing points are known, Coleman et al. (1997) suggested a minimum of $9 \mathrm{~km}$ displacement on the basis of the apparent offset of Devonian Simonson Dolomite. The initial dip of the fault is not well defined, but the inferred displacement is equivalent to a minimum throw of $7.8 \mathrm{~km}$ for a $60^{\circ} \mathrm{dip}$, and $4.5 \mathrm{~km}$ for a $30^{\circ} \mathrm{dip}$. Nielson et al. (1986) estimated that slip on the Cave Canyon detachment began at $7 \mathrm{~km}$ depth, from a comparison of the estimated presentday geothermal gradient at Roosevelt Hot Springs in the northern Mineral Mountains and the temperature needed to produce a granitic mylonite (their estimate, 430 and 480 ${ }^{\circ} \mathrm{C}$ ). However, as noted herein, we found no evidence for mylonite development in the granitic rocks. The ${ }^{40} \mathrm{Ar} /{ }^{39} \mathrm{Ar}$ cooling ages suggest that the footwall granite had cooled to $<300$ ${ }^{\circ} \mathrm{C}$ prior to development of the detachment (Coleman et al., 1997).
The overall pattern of deformation and mineralization in footwall rocks is similar to that described by Bruhn et al. (1982) for the Wild Horse Canyon fault (Fig. 1) in the northern Mineral Mountains. There, these authors described an altered cataclasite consisting of comminuted quartz and feldspar surrounded by a greenschist assemblage of newly grown sericite, chlorite, epidote, and clay minerals. They cited fluid-inclusion data indicating alteration at $200-300{ }^{\circ} \mathrm{C}$, and suggested a depth of faulting of no more than $5 \mathrm{~km}$. The geothermal gradient was undoubtedly elevated in the vicinity of the batholith. If the interpretations of Bruhn et al. (1982) also apply to the Cave Canyon detachment, and the estimates of Coleman (1991) for the emplacement depth of the batholith are correct, then significant uplift and exhumation is implied prior to the development of the detachment.

\section{Pressure-Temperature Conditions at the Hypothesized Sevier Desert Detachment}

To the extent that no evidence for deformation has been observed at the level of the 

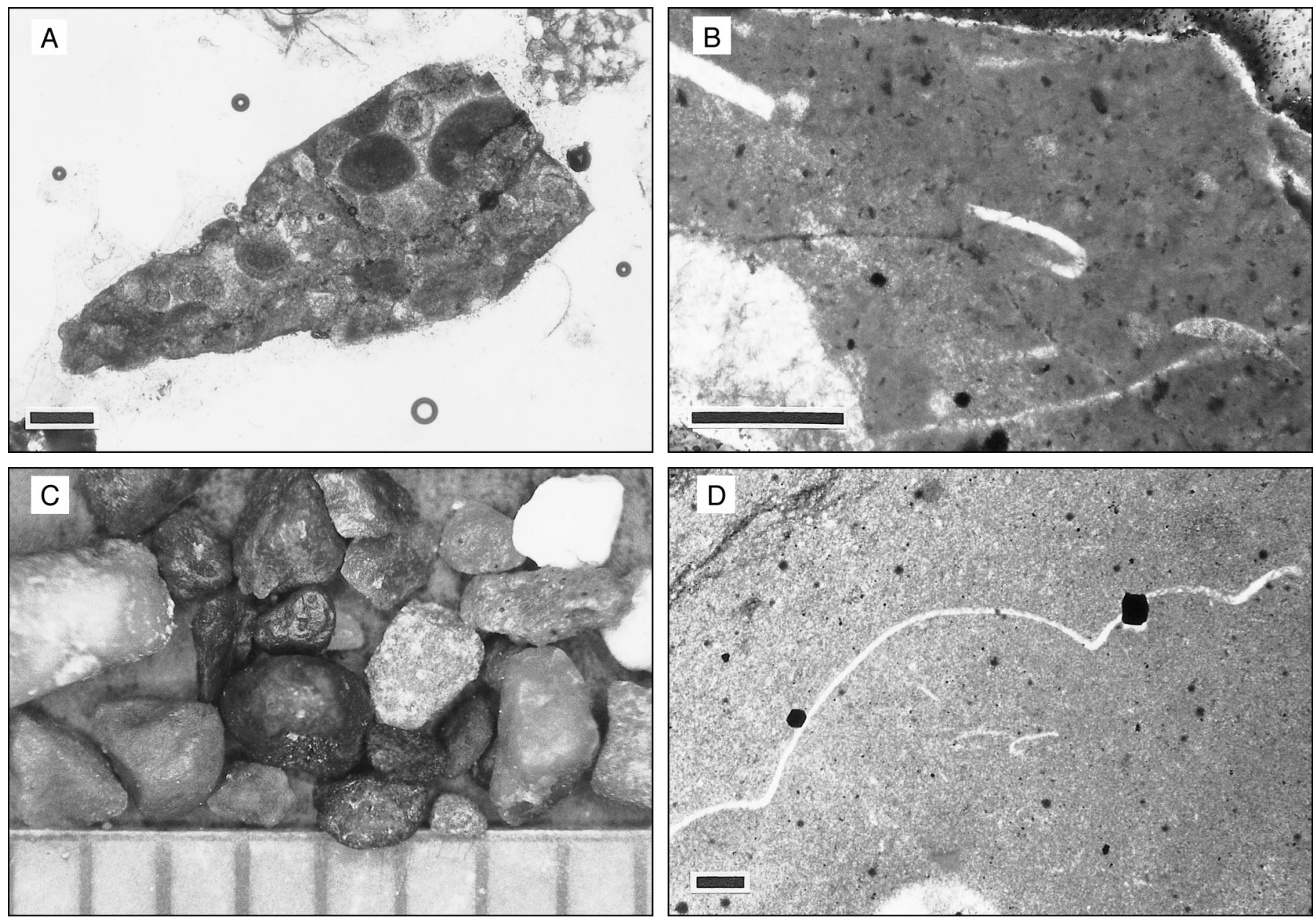

Figure 8. Photomicrographs from cuttings collected near Tertiary-Paleozoic contact in ARCO Meadow Federal No. 1 (AMF), Argonaut Energy Federal No. 1 (AE), and ARCO Hole-in-the-Rock No. 1 (AHR) wells (Fig. 1). Scale bar is 0.4 mm in A, C, and D. In B, tickmark interval is $1 \mathrm{~mm}$. (A) Ooids in chip from interval containing Tertiary-Paleozoic contact in AMF well. No ooids were found in cuttings above the contact. (B) Hook-shaped fossil fragment from interval between 1780.0 and $1783.1 \mathrm{~m}$ in AMF well. (C) Well-rounded granules of volcanic rock, quartzite, and carbonate recovered from interval containing Tertiary-Paleozoic contact in AE well. (D) Wackestone containing trilobite fragments from core recovered $\mathbf{1 2 . 8} \mathbf{~ m}$ below Tertiary-Paleozoic contact in AHR well. Large fossil is a section of a trilobite cephalon. Numerous hook-shaped fragments are thought to be from cephalon rims. Very similar fragments are present in cuttings up to the base of Tertiary section (see B). The average calcite grain size is about 5 $\mu \mathrm{m}$.

inferred Sevier Desert detachment, estimates for the depth and temperature at which deformation may have taken place depend entirely on the manner in which the detachment is reconstructed. For the Tertiary sedimentary rocks, the maximum depth of faulting is simply the present depth of the Tertiary-Paleozoic contact: $2.8 \mathrm{~km}$ at the AHR well, $2.4 \mathrm{~km}$ at the $\mathrm{AE}$ well, and $1.8 \mathrm{~km}$ at the AMF well. The depth at which deformation began, as monitored by the Paleozoic rocks of the inferred footwall, must be considerably greater, in excess of $9 \mathrm{~km}$ at the wells that we have studied. Temperatures would have been in excess of $280-375^{\circ} \mathrm{C}$ (AMF and AHR wells), and perhaps as great as $425^{\circ} \mathrm{C}$ (AE well).
Allmendinger et al. (1983), Von Tish et al. (1985), and Allmendinger (1992) traced the hypothesized detachment for $70 \mathrm{~km}$ to the west along COCORP Utah Line 1 (Fig. 1), and to a depth of about $15 \mathrm{~km}$. Assuming a net slip of 38-40 km (Allmendinger, 1992; Coogan and DeCelles, 1996), and a detachment dip comparable to that determined in Line 1, Paleozoic rocks immediately beneath the detachment in the AE well, $22 \mathrm{~km}$ north of Line 1, would originally have been at a depth of $14 \mathrm{~km}$. The footwall Paleozoic rocks would have been at depths of at least $12 \mathrm{~km}$ in the AHR well and $9 \mathrm{~km}$ in the AMF well, again assuming (with Royse, 1993) that the dip of the detachment is the same as that in- terpreted at Line 1. Each of these figures exceeds our earlier estimate of between 7 and 8 $\mathrm{km}$ for the depth of faulting (Anders and Christie-Blick, 1994). The lower figure was obtained by using the lower displacement assessment $(28 \mathrm{~km})$ of Von Tish et al. (1985). All of our depth estimates should be regarded as minima for their respective locations, owing to erosion and other normal faulting since the time detachment faulting began.

A crude estimate of the initial temperature of the footwall rocks can be derived from zircon fission-track data from depths of between 4.1 and $4.7 \mathrm{~km}$ in the AMF well (Allmendinger and Royse, 1995). Closure ages for the samples range from $10.8 \pm 0.9$ Ma to $13.0 \pm$ 
1.0 Ma. Assuming a zircon closure temperature of $250{ }^{\circ} \mathrm{C}$ and a constant rate of displacement on the detachment since $26 \mathrm{Ma}$, at 13 Ma the displacement would have been $19 \mathrm{~km}$, or about half its inferred displacement today. If the cross sections of Allmendinger (1992) or Royse (1993) are assumed, Paleozoic rocks in the AMF well would have been at a depth of at least $5 \mathrm{~km}$. The fission-track samples were obtained from a depth $3 \mathrm{~km}$ below the Tertiary-Paleozoic contact. Assuming for the sake of simplicity that the temperature gradient was both constant with depth and invariant with time over the preceding 13 m.y., then the initial temperature at the top of the Paleozoic section (9 km depth) would have been $280{ }^{\circ} \mathrm{C}$. In the AHR well, the temperature of the uppermost Paleozoic rocks (12 km depth) would have been $375{ }^{\circ} \mathrm{C}$. These estimates are conservative, because the region around the southern wells (AMF and AHR) was volcanically active and unroofing would have led to cooling of footwall rocks.

The temperature of the Paleozoic rocks in the $\mathrm{AE}$ well is less well defined than for the AMF and AHR wells. However, we think that the detachment model calls for a still greater temperature for the Paleozoic rocks at the $\mathrm{AE}$ well than at the other two. Projecting the location of the AE well south onto COCORP Utah Line 1 (Fig. 1) yields a restored depth to the top of the Paleozoic section of $14 \mathrm{~km}$. This is a minimum for the faulting model assuming no erosion. Restoring $38 \mathrm{~km}$ of east-west extension along the proposed detachment places the Drum and Little Drum Mountains (Fig. 1) directly above the Paleozoic rocks of the AE well. The Drum and Little Drum Mountains are the site of a major volcanic center from middle Eocene to late Miocene time (time scale of Berggren et al., 1995). Eruption of extensive rhyodacite flows began at $41.8 \pm$ $2.3 \mathrm{Ma}$, followed by the development of diorite plugs at $36.4 \pm 1.6 \mathrm{Ma}$, porphyritic rhyolites at $21.2 \pm 0.9 \mathrm{Ma}$, and rhyolite flows and domes at $6.8 \pm 0.3 \mathrm{Ma}$ to $6.3 \pm 0.4 \mathrm{Ma}$ (Lindsey, 1979). Other volcanic rocks are locally interlayered with these units, but they are undated (Pierce, 1974; Lindsey, 1979, 1982). Prefaulting heat flow for the area occupied by the Drum and Little Drum Mountains can be estimated several ways. For example, Lachenbruch and Sass (1978) determined the characteristic Basin and Range heat flow as between 70 and $90 \mathrm{~mW} / \mathrm{m}^{2}$. Conservatively assuming the minimum characteristic heat flow estimate of $70 \mathrm{~mW} / \mathrm{m}^{2}$ for the Drum and Little Drum Mountains just before $28 \mathrm{Ma}$, the presumed starting time for faulting (Von Tish et al., 1985), yields a temperature of $325{ }^{\circ} \mathrm{C}$ at the contact. As noted herein, however, volcanism in the area brackets the $28 \mathrm{Ma}$ assumed initiation of faulting, a factor that can further refine the heat flow estimate through comparison with measurements in currently active volcanic provinces. Measurements along the margin of the Snake River Plain, $\sim 50 \mathrm{~km}$ from a migrating series of eruptive calderas, yield heat flow values typically greater than $100 \mathrm{~mW} / \mathrm{m}^{2}$, and as high as 200 $\mathrm{mW} / \mathrm{m}^{2}$, even $12 \mathrm{~m} . \mathrm{y}$. after passage of a migrating thermal source (see Brott et al., 1981; Blackwell, 1989; Anders and Sleep, 1992). Assuming a conservative $100 \mathrm{~mW} / \mathrm{m}^{2}$ for a volcanic complex within a few million years of the last major eruption, the temperature at $14 \mathrm{~km}$ would have been $>425{ }^{\circ} \mathrm{C}$ at $28 \mathrm{Ma}$.

\section{DISCUSSION}

We readily acknowledge uncertainties in our assessment of ambient pressure-temperature conditions during movement along the Cave Canyon detachment and during the hypothesized faulting at the base of the Sevier Desert basin. However, available evidence suggests that the Cave Canyon detachment was active at a considerably shallower and cooler level in the crust $(\sim 5 \mathrm{~km}$ and $<300$ ${ }^{\circ} \mathrm{C}$ ) than might be inferred from the depth of emplacement of the batholith that it cuts, and significantly shallower and cooler than the Paleozoic rocks beneath the Sevier Desert once the hanging-wall rocks are restored along the hypothesized detachment $(9-14 \mathrm{~km}$ and $280-425^{\circ} \mathrm{C}$ ). Because we observe mylonitization in hanging-wall carbonate rocks of the Cave Canyon detachment, we expect mylonitization in carbonate rocks in the footwall of the hypothesized Sevier Desert detachment at the depths and temperatures predicted for the onset of faulting.

Previous work has shown that at depths as shallow as $1.7 \mathrm{~km}$, and at temperatures below $200{ }^{\circ} \mathrm{C}$ (and possibly below $100{ }^{\circ} \mathrm{C}$ ), normal faults achieve deviatoric stress levels that are sufficiently great to produce healed microfractures (Anders and Wiltschko, 1994; Vermilye, 1996). It is therefore reasonable to expect such features to have developed at the hypothesized detachment once the basin fill had become sufficiently thick $(1.8-2.8 \mathrm{~km}$ depth in the wells studied). Von Tish et al. (1985) suggested that the strong reflectivity of the surface might be due to the presence of a thick cataclastic zone. The lack of a microfracture aureole, comparable to the one observed at the Cave Canyon detachment, was the prime evidence used by Anders and Christie-Blick
(1994) to argue that the Sevier Desert detachment does not exist.

Is it possible that the evident contrasts in associated deformation between the two examples are due to different deformation mechanisms along normal faults with initially different dip? The Sevier Desert detachment is usually regarded as having developed with an inclination not much different from its present $11^{\circ}$ dip, albeit with a more steeply dipping breakaway ramp in the vicinity of the Canyon Range (Otton, 1995). In contrast, the Cave Canyon detachment has been cited as an example of rolling hinge tectonics (e.g., Buck, 1988), initiating at a high angle, and rotating to a $20^{\circ}$ dip on the west side of the Mineral Mountains and to subhorizontal dips on the east side of the range (Coleman and Walker, 1994; Coleman et al., 1997). To the best of our knowledge, the rock in a fault zone senses only the ambient stress field, regardless of the orientation of the plane of failure (see Scholz, 1990). Many of the models that attempt to explain the mechanical behavior of low-angle normal faults, or the paradox of low-angle normal faults, call on deflection of the maximum principal stress from vertical to a low angle in the brittle crust (e.g., Yin, 1989; Spencer and Chase, 1989; Parsons and Thompson, 1993). Although a special localized failure condition has been proposed (Axen, 1992), its fundamental mechanical underpinning has been challenged (Scholz, 1992, 2000).

The age of the Sevier Desert basin is not well defined, and yet exceedingly pertinent to hypotheses of basin development. An Eocene flora was reported at the base of the Tertiary section in the ARCO drilling report for the AHR well. Carbonized plant fragments (coal) and feldspar are clearly visible in the cuttings from the interval between 2773.7 and 2779.8 $\mathrm{m}$. The presence of feldspar and coal is consistent with, although not necessarily diagnostic of, the Eocene Colton Formation. If grains of ash-flow tuff found in this volcanic-poor interval are not downhole contaminants, the sedimentary rocks could be as old as late Eocene to early Oligocene, the time of the first volcanic eruption in the area. Of particular interest are the volcanic-free quartzite-bearing sandstones in the basal 15.2 m of Tertiary strata in the AMF well. Sandstones of this sort are common in the North Horn Formation of Late Cretaceous to Paleocene age. If pre-Oligocene ages are verified in future studies, they pose an additional difficulty for the detachment hypothesis.

We have already drawn attention to implications of volcanic rocks in the Drum and Lit- 
tle Drum Mountains for the temperature of the Paleozoic rocks intersected by the $\mathrm{AE}$ well at the onset of detachment faulting. The volcanic rocks span the interval from nearly $42 \mathrm{Ma}$ to ca. 6 Ma (Lindsey, 1979), during which time they are supposed to have been transported westward by nearly $40 \mathrm{~km}$. It is unclear in the detachment hypothesis why volcanism persisted for some 36 m.y. in a structural block that moved so far from its presumed deep volcanic source, or why the motion of that block over the magmatic source is not marked by some kind of volcanic track. Large plutons freeze in $\sim 1-2$ m.y. (Lachenbruch et al., 1976). Therefore, new sources, assumed lithospheric, would have to migrate in tandem with the hanging wall of the detachment-an unlikely prospect.

\section{CONCLUSIONS}

We investigated the characteristics and mechanisms of deformation at a surface exposure of the Cave Canyon detachment in the Mineral Mountains of west-central Utah, a fault inferred by Coleman et al. (1997) to represent an upper plate splay of the Sevier Desert detachment. The Cave Canyon detachment is characterized by a 200-m-thick zone of cataclastic granite, overlain by $9 \mathrm{~m}$ of deformed partially dolomitized limestone, with a 2-m-thick carbonate mylonite at the fault contact. The absence of evidence in borehole samples for comparable deformation at the Tertiary-Paleozoic contact beneath the Sevier Desert cannot be reconciled with the existence of a detachment at that surface. The Cave Canyon detachment was active at depths as shallow as $5 \mathrm{~km}$, and at temperatures most likely below $300{ }^{\circ} \mathrm{C}$. Restoration of $38-40$ $\mathrm{km}$ of displacement along the hypothesized Sevier Desert detachment suggests that at the wells studied, Paleozoic carbonate rocks of the purported footwall of the detachment would, at the time deformation began, have been at a depth of at least $9-14 \mathrm{~km}$, and at a temperature of at least $280-425{ }^{\circ} \mathrm{C}$. Mylonitization would have been inevitable under those conditions. Similarly, at the wells studied, the Tertiary section is sufficiently deep $(1.8-2.8 \mathrm{~km})$ that microfracturing of quartz should be abundant.

If the Tertiary-Paleozoic contact beneath the Sevier Desert is not a detachment, our study implies that the total amount of extension across this part of the Basin and Range Province is substantially less than previously interpreted. It implies that published reconstructions of Mesozoic thrust faults in this segment of the Sevier orogen need to be reevaluated.
It requires reconsideration of the mechanisms that may have been responsible for the development of the Sevier Desert basin. Our study provides an impetus to question the observational basis for interpreting displacement at low dip along other low-angle normal faults.

\section{ACKNOWLEDGMENTS}

We thank Vastar Resources, a subsidiary of Atlantic Richfield Corporation (ARCO), for permission to examine seismic and well data from the Sevier Desert basin, for allowing us to sample cuttings and core from wells, and for permission to publish selected data. In particular, we thank Fred Metzger, formerly of Atlantic Richfield, for his assistance in early sampling of the ARCO wells. This research benefited from extensive discussions with Doug Sprinkel, Lehi Hintze, Georg Dresen, and Gary Mitchell. The manuscript was improved by reviews from Steve Wojtal, Jeff Lee, Rick Law, Jud May, and Fred Dula. Ann Holmes and Charlotte Schreiber helped with fossil identification, and Maureen Anders helped with graphics. Support was provided by the Donors of the Petroleum Research Fund, administered by the American Chemical Society, grant 32194-AC2, and by National Science Foundation (NSF) grant EAR-99-02782. We acknowledge Tom Wright at the NSF Tectonics Program for his willingness to support research that diverges from the conventional wisdom on low-angle normal faults. Lamont-Doherty Earth Observatory Contribution 6165 .

\section{REFERENCES CITED}

Abers, G.A., 1991, Possible seismogenic shallow-dipping normal faults in the Woodlark-D'Entrecasteaux extensional province, Papua New Guinea: Geology, v. 19, p. 1205-1208.

Allmendinger, R.W., 1992, Fold and thrust tectonics of the western United States exclusive of the accreted terranes, in Burchfiel, B.C., et al., eds., The Cordilleran orogen: Conterminous U.S.: Boulder, Colorado, Geological Society of America, Geology of North America, v. G-3, p. 583-607.

Allmendinger, R.W., and Royse, F., Jr., 1995, Is the Sevier Desert reflection of west-central Utah a normal fault?: Comment: Geology, v. 23, p. 669-670.

Allmendinger, R.W., Sharp, J.W., Von Tish, D., Serpa, L., Brown, L., Kaufman, S., Oliver, J., and Smith, R.B., 1983. Cenozoic and Mesozoic structure of the eastern Basin and Range province, Utah, from COCORP seismic-reflection data: Geology, v. 11, p. 532-536.

Anders, M.H., and Christie-Blick, N., 1994, Is the Sevier Desert reflection of west-central Utah a normal fault? Geology, v. 22, p. 771-774.

Anders, M.H., and Sleep, N.H., 1992, Magmatism and extension: The thermal and mechanical effects of the Yellowstone hotspot: Journal of Geophysical Research, v. 97, p. 15379-15393.

Anders, M.H., and Wiltschko, D.V., 1994, Microfracturing, paleostress and the growth of faults: Journal of Structural Geology, v. 16, p. 795-815.

Anders, M.H., Christie-Blick, N., and Wills, S., 1998, Extensional collapse along the Sevier Desert reflection, northern Sevier Desert basin, western United States: Comment: Geology, v. 26, p. 474.

Anderson, E.M., 1942, The dynamics of faulting and dyke formation with applications to Britain: Edinburgh, Oliver and Boyd, $191 \mathrm{p}$.

Armstrong, R.L., 1972, Low-angle (denudation) faults, hinterland of the Sevier orogenic belt, eastern Nevada and western Utah: Geological Society of America Bulletin, v. 83, p. 1729-1754.
Armstrong, R.L., 1982, Cordilleran metamorphic core complexes-From Arizona to southern Canada: Annual Review of Earth and Planetary Sciences, v. 10, p. 129-154.

Axen, G.J., 1992, Pore pressure, stress increase, and fault weakening in low-angle normal faulting: Journal of Geophysical Research, v. 97, p. 8979-8991.

Barker, C.A., 1986, Upper-crustal structure of the Milford Valley and Roosevelt Hot Springs, Utah region, by modeling of seismic refraction and reflection data [M.S. thesis]: Salt Lake City, University of Utah, $101 \mathrm{p}$.

Berggren, W.A., Kent, D.V., Swisher, C.C., III, and Aubry, M.-P., 1995, A revised Cenozoic geochronology and chronostratigraphy, in Berggren, W.A., et al., eds., Geochronology, time scales and global stratigraphic correlation: SEPM (Society for Sedimentary Geology) Special Publication 54, p. 129-212.

Blackwell, D.D., 1989, Regional implications of heat flow of the Snake River Plain, northwestern United States: Tectonophysics, v. 164 , p. 323-343.

Brock, W.G., and Engelder, T., 1977, Deformation associated with the movement of the Muddy Mountain overthrust in the Buffington window, southeastern Nevada: Geological Society of America Bulletin, v. 88, p. $1667-1677$.

Brott, C.A., Blackwell, D.D., and Ziagos, J.P., 1981, Thermal and tectonic implications of heat flow in the eastern Snake River Plain, Idaho: Journal of Geophysical Research, v. 86, p. 11709-11734.

Bruhn, R.L., Yusas, M.R., and Huertas, F., 1982, Mechanics of low-angle normal faulting: An example from Roosevelt Hot Springs geothermal area, Utah: Tectonophysics, v. 86, p. 343-361.

Buck, W.R., 1988, Flexural rotation of normal faults: Tectonics, v. 7, p. 959-973.

Burkhard, M., 1993, Calcite twins, their geometry, appearance and significance as stress-strain markers and indicators of tectonic regime: A review: Journal of Structural Geology, v. 15 , p. 351-368.

Coleman, D.S., 1991, Geology of the Mineral Mountains batholith, Utah [Ph.D. dissertation]: Lawrence, University of Kansas, 219 p.

Coleman, D.S., and Walker, J.D., 1992, Evidence for the generation of juvenile granitic crust during continental extension, Mineral Mountains batholith, Utah: Journal of Geophysical Research, v. 97, p. 11011-11024.

Coleman, D.S., and Walker, J.D., 1994, Modes of tilting during extensional core complex development: Science, v. 263, p. 215-218.

Coleman, D.S., Bartley, J.M., Walker, J.D., Price, D.E., and Friedrich, A.M., 1997, Extensional faulting, footwall deformation and plutonism in the Mineral Mountains, southern Sevier Desert, in Link, P.K., and Kowallis, B.J., eds., Mesozoic to recent geology of Utah: Brigham Young University Geology Studies, v. 42, part 2, p. 203-233.

Coogan, J.C., and DeCelles, P.G., 1996, Extensional collapse along the Sevier Desert reflection, northern Sevier Desert basin, western United States: Geology, v. 24, p. 933-936.

Crittenden, M.D., Jr., Coney, P.J., and Davis, G.H., eds., 1980, Cordilleran metamorphic core complexes: Geological Society of America Memoir 153, 490 p.

DeCelles, P.G., Lawton, T.F., and Mitra, G., 1995, Thrust timing, growth of structural culminations, and synorogenic sedimentation in the type Sevier orogenic belt, western United States: Geology, v. 23, p. 699-702.

Drury, M.R., 1993, Deformational lamellae in metals and minerals, in Boland, J.N., and Fitzgerald, J.D., eds., Defects and processes in the solid state: Geoscience applications: McLaren volume: Amsterdam, The Netherlands, Elsevier, p. 195-212.

Engelder, J.T., 1974, Cataclasis and the generation of fault gouge: Geological Society of America Bulletin, v. 85, p. $1515-1522$.

Hamilton, W., 1994, “Sevier Desert detachment," UtahA nonexistent structure: Geological Society of America Abstracts with Programs, v. 26, no. 2, p. 57.

Kerr, R.A., 1993, Geologists get together to dissect earth's thin skin: Science, v. 262, p. 992-993.

Lachenbruch, A.H., and Sass, J.H., 1978, Models of an extending lithosphere and heat flow in the Basin and 


\section{IMPLICATIONS FOR UPPER CRUSTAL LOW-ANGLE NORMAL FAULTING}

Range province, in Smith, R.B., and Eaton, G.P., eds., Cenozoic tectonics and regional geophysics of the western Cordillera: Geological Society of America Memoir 152, p. 209-250.

Lachenbruch, A.H., Sass, J.H., Munroe, R.J., and Moses, T.H., Jr., 1976, Geothermal setting and simple heat conduction models for the Long Valley caldera: Journal of Geophysical Research, v. 81, p. 769-784.

Lindsey, D.A., 1979, Geologic map and cross-sections of Tertiary rocks in the Thomas Range and northern Drum Mountains, Juab County, Utah: U.S. Geological Survey Miscellaneous Investigations Series Map I1176, scale 1:62 500.

Lindsey, D.A., 1982, Tertiary volcanic rocks and uranium in the Thomas Range and northern Drum Mountains, Juab County, Utah: U.S. Geological Survey Professional Paper 1221, $71 \mathrm{p}$.

Lindsey, D.A., Glanzman, R.K., Naeser, C.W., and Nichols, D.J., 1981, Upper Oligocene evaporites in basin fill of Sevier Desert region, western Utah: American Association of Petroleum Geologists Bulletin, v. 65, p. 251-260

McDonald, R.E., 1976, Tertiary tectonics and sedimentary rocks along the transition: Basin and Range Province to plateau and thrust belt province, Utah, in Hill, J.G., ed., Geology of the Cordilleran hingeline: Denver, Colorado, Rocky Mountain Association of Geologists, p. 281-317.

Mitchell, G.C., 1979, Stratigraphy and regional implications of the Argonaut Energy No. 1 Federal, Millard County, Utah, in Newman, G.W., and Goode, H.D., eds., Basin and Range symposium and Great Basin field conference: Denver, Colorado, Rocky Mountain Association of Geologists, p. 503-514.

Mitchell, G.C., and McDonald, R.E., 1987, Subsurface Tertiary strata, origin, depositional model and hydrocarbon exploration potential of the Sevier Desert basin, west central Utah, in Kopp, R.S., and Cohenour, R.E., eds., Cenozoic geology of western Utah: Utah Geological Association Publication 16, p. 533-556.

Newman, J., and Mitra, G., 1994, Fluid-influenced deformation and recrystallization of dolomite at low temperatures along a natural fault zone, Mountain City window, Tennessee: Geological Society of America Bulletin, v. 106, p. 1267-1280.

Nielson, D.L., Evans, S.H., Jr., and Sibbett, B.S., 1986,
Magmatic, structural, and hydrothermal evolution of the Mineral Mountains intrusive complex, Utah: Geological Society of America Bulletin, v. 97, p. 765-777.

Otton, J.K., 1995, Western frontal fault of the Canyon Range: Is it the breakaway zone of the Sevier Desert detachment?: Geology, v. 23, p. 547-550.

Parsons, T., and Thompson, G.A., 1993, Does magmatism influence low-angle normal faulting?: Geology, v. 21, p. $247-250$.

Pierce, C.R., 1974, Geology of the southern part of the Little Drum Mountains, Utah: Brigham Young University Geology Studies, v. 21, part 1, p. 109-130.

Planke, S., and Smith, R.B., 1991, Cenozoic extension and evolution of the Sevier Desert basin, Utah, from seismic reflection, gravity, and well log data: Tectonics, v. 10 , p. $345-365$.

Royse, F., Jr., 1993, Case of the phantom foredeep: Early Cretaceous in west-central Utah: Geology, v. 21, p. 133-136.

Royse, F., Jr., Warner, M.A., and Reese, D.L., 1975, Thrust belt structural geometry and related stratigraphic problems, Wyoming-Idaho-northern Utah, in Bolyard, D.W., ed., Deep drilling frontiers of the central Rocky Mountains: Denver, Rocky Mountain Association of Geologists Symposium, p. 41-54

Scholz, C.H., 1990, The mechanics of earthquakes and faulting: Cambridge, Cambridge University Press, 439 p.

Scholz, C.H., 1992, Weakness amidst strength: Nature, v. 359, p. 677-678.

Scholz, C.H., 2000, Evidence for a strong San Andreas fault: Geology, v. 28, p. 163-166.

Scholz, C.H., Dawers, N.H., Yu, J.-Z., Anders, M.H., and Cowie, P.A., 1993, Fault growth and fault scaling laws: Preliminary results: Journal of Geophysical Research, v. 98, p. 21951-21961.

Smith, R.B., and Bruhn, R.L., 1984, Intraplate extensional tectonics of the eastern Basin-Range: Inferences on structural style from seismic reflection data, regional tectonics, and thermal-mechanical models of brittleductile deformation: Journal of Geophysical Research, v. 89 , p. $5733-5762$.

Spencer, J.E., and Chase, C.G., 1989, Role of crustal flexure in initiation of low-angle normal faults and implications for structural evolution of the Basin and Range Province: Journal of Geophysical Research, v. 94, p. 1765-1775.
Urai, J.L., Means, W.D., and Lister, G.S., 1986, Dynamic recrystallization in minerals, in Hobbs, B.E., and Heard, H.C., eds., Mineral and rock deformation: Laboratory studies: American Geophysical Union Geophysical Monograph Series 36, p. 161-199.

Vermilye, J.M., 1996, The growth of natural fracture systems: A fracture mechanics approach [Ph.D. dissertation]: New York, Columbia University, 236 p.

Vermilye, J.M., and Scholz, C.H., 1998, The process zone: A microstructural view of fault growth: Journal of Geophysical Research, v. 103, p. 12223-12237.

Von Tish, D.B., Allmendinger, R.W., and Sharp, J.W., 1985, History of Cenozoic extension in central Sevier Deser west-central Utah, from COCORP seismic reflection data: American Association of Petroleum Geologists Bulletin, v. 69, p. 1077-1087.

Wernicke, B., 1981, Low-angle normal faults in the Basin and Range Province: Nappe tectonics in an extending orogen: Nature, v. 291, p. 645-648.

Wernicke, B., 1985, Uniform-sense normal simple shear of the continental lithosphere: Canadian Journal of Earth Sciences, v. 22, p. 108-125.

Wernicke, B., 1995, Low-angle normal faults and seismicity: A review: Journal of Geophysical Research, v 100, p. 20159-20174.

Wernicke, B., and Burchfiel, B.C., 1982, Modes of extensional tectonics: Journal of Structural Geology, v. 4, p. $105-115$.

Wills, S., 2000, Evaluating models of detachment faulting [Ph.D. dissertation]: New York, Columbia University, $381 \mathrm{p}$.

Wojtal, S., and Mitra, G., 1986, Strain hardening and strain softening in fault zones from foreland thrusts: Geological Society of America Bulletin, v. 97, p. 674-687.

Wright, L.A., and Troxel, B.W., 1973, Shallow-fault interpretation of Basin and Range structure, southwestern Great Basin, in DeJong, K.A., and Scholten, R., eds., Gravity and tectonics: New York, John Wiley, p. 397 407.

Yin, A., 1989, Origin of regional, rooted low-angle normal faults: A mechanical model and its tectonic implications: Tectonics, v. 8, p. $469-482$

Manuscript Received by the Society February 17, 1999 Revised Manuscript Received June 16, 2000 MANUSCRIPT ACCEPTED JULY 12, 2000

Printed in the USA 